\title{
Solid feed provision reduces fecal clostridial excretion in veal calves
}

\author{
Het geven van vaste voeding aan witvleeskalveren vermindert de uitscheiding \\ van clostridia in de mest
}

\begin{abstract}
${ }^{1}$ B. Valgaeren, ${ }^{1}$ H. Hanssens, ${ }^{2}$ S. Roelandt, ${ }^{3}$ E. Goossens, ${ }^{3}$ S. Verherstraeten, ${ }^{1}$ L. Gille, ${ }^{1}$ L. Van Driessche, ${ }^{3} \mathrm{~F}$. Haesebrouck, ${ }^{3} \mathrm{R}$. Ducatelle, ${ }^{3} \mathrm{~F}$. Van Immerseel, ${ }^{1} \mathrm{P}$. Deprez, ${ }^{1} \mathrm{~B}$. Pardon

${ }^{1}$ Department of Large Animal Internal Medicine, Faculty of Veterinary Medicine, Ghent University, Salisburylaan 133, 9820 Merelbeke, Belgium

${ }^{2}$ Unit for Coordination of Veterinary Diagnosis, Epidemiology and Risk Assessment (CVD-ERA), Veterinary and Agrochemical Research Centre (VAR-CODA-CERVA), Brussels, Belgium

${ }^{3}$ Department of Pathology, Bacteriology and Avian Diseases, Faculty of Veterinary Medicine, Ghent University, Salisburylaan 133, 9820 Merelbeke, Belgium
\end{abstract}

bonnie.valgaeren@ugent.be

\section{$\Lambda_{\text {bstract }}$}

Enterotoxemia is characterized by a highly fatal hemorrhagic enteritis in cattle, caused by Clostridium perfringens. Production systems with intensive feeding, such as the veal industry, are predisposed. The primary objective of this study was to determine the effect of solid feed provision on fecal $C$. perfringens excretion in veal calves. Ten Holstein Friesian bull veal calves were randomly assigned to one of two test diets. Group 1 received solemnly milk replacer twice daily, while group 2 received milk replacer and a maximum of $300 \mathrm{~g}$ solid feed/day, consisting of a mixture of $30 \%$ barley, $30 \%$ corn, $30 \%$ hulled wheat and $10 \%$ chopped straw. The number of $C$. perfringens per $\mathrm{g}$ feces or fecal clostridial counts (FCC) were determined for all calves. Mean FCC were significantly lower in the calves fed milk replacer and solid feed, than in the calves fed solemnly milk replacer. Although the correlation between FCC and enterotoxemia risk remains to be determined, the provision of solid feed to veal calves reduced clostridial excretion, which might contribute to the prevention of this disease.

\section{SAMENVATTING}

Clostridium perfringens geassocieerde enterotoxemie is een belangrijke oorzaak van sterfte bij kalveren in intensieve opfoksystemen. Het doel van deze studie was om het effect van vaste voeding te beoordelen op de uitscheiding van C. perfringens in de mest bij witvleeskalveren. Twee verschillende testdiëten werden at random toegewezen aan tien holsteinfriesian-witvleeskalveren. De kalveren in groep 1 werden uitsluitend gevoed met melkpoeder, terwijl kalveren in groep 2 zowel melkpoeder als een maximum van $300 \mathrm{~g}$ vaste voeding per voederbeurt kregen. De vaste voeding bestond uit $30 \%$ gerst, $30 \%$ mais, $30 \%$ tarwe en $10 \%$ gehakseld stro. Vervolgens werd het aantal clostridia in de mest bepaald. Kalveren die zowel melkpoeder als vaste voeding kregen, scheidden significant minder clostridia uit in de mest dan kalveren die uitsluitend met melkpoeder werden gevoed. Er moet nog verder onderzocht worden of het verschaffen van vaste voeding aan witvleeskalveren een preventief effect heeft op enterotoxemie.

\section{SHORT COMMUNICATION}

Enterotoxemia (hemorrhagic enteritis) is a highly fatal disease in cattle, caused by Clostridium perfringens. The disease predominantly affects calves in intensive production systems, such as the veal industry or feedlots (Griner and Bracken, 1953; Niilo et al., 1974, Glock and Degroot, 1998; Muylaert et al., 2010). In Belgian blue veal calves, enterotoxemia accounts for $20 \%$ of the total mortality rate $(5-7 \%)$ and occurs predominantly at the end of the production cycle when animals have a high economic value (Pardon et al., 2012). Given the high fatality rate and rapid course of the disease, control is mainly focused 
on prevention. It is generally accepted that especially dietary factors, such as high protein diets are associated with the enterotoxemia risk (Lebrun et al., 2010). Therefore, dietary adaptations might help in the prevention of the disease. Traditionally, white veal calves are not fed any solid feed in order to maintain the desired pale meat color. In recent years, several studies have demonstrated beneficial effects of the provision of solid feed on ruminal development, daily growth and animal welfare, without negative effects on meat color (Suarez et al., 2007; Webb et al., 2013). Moreover, for welfare reasons, European legislation obliges a minimum provision of solid feed (European Council Directive 2008/119/EC). It is hitherto unclear what the consequences of solid feed provision are with respect to the risk of developing enterotoxemia. It is believed that fiber-rich feeds inhibit clostridial overgrowth, by altering the intestinal microbiota (Zhang et al., 2013). Thus, the hypothesis of the present study was that solid feed provision would reduce the fecal excretion of $C$. perfringens in veal calves.

To determine the effect of solid feed provision on fecal $C$. perfringens excretion a cross-sectional study was conducted on a commercial white veal farm $(5000$ animals present). To determine a one log difference between test groups, with a standard deviation of 40 CFU (colony forming units)/g feces, 95\% confidence and $80 \%$ power, a sample size of 5 animals per test group was required. All procedures were approved by the local ethical committee (EC2014/016). Ten male Holstein Friesian calves (mean body weight $=52 \mathrm{~kg}$; mean age $=14$ days) were randomly assigned to one of two test groups (group 1 and group 2) on the day of arrival at the fattening unit. All calves were kept on a slatted floor without bedding. Calves were not vaccinated against Clostridia. However, both groups received amoxycilline in the first ten days after arrival at the fattening unit as a preventive start-up treatment. Both groups were fed the same amount and concentration of a commercial milk replacer (Nil product, Vilatca nv, Geel, Belgium), twice daily. The milk replacer provision increased from $220 \mathrm{~g}$ DM (dry matter)/day on arrival to $750 \mathrm{~g} \mathrm{DM} /$ day at the age of three months. The milk replacer contained $8 \%$ ash, $17.7 \%$ crude fat and $18 \%$ crude protein $(\mathrm{CP})$ (whey, vegetal protein, no casein) per feeding. Group 2 received solid feed once daily in addition to the milk replacer, starting with $32 \mathrm{~g} \mathrm{FP}$ (fresh product)/feeding gradually increasing to $300 \mathrm{~g} \mathrm{FP} /$ feeding at the age of three months. The solid feed consisted of a mixture of whole grains (barley (30\%), corn (30\%), hulled wheat $(30 \%)$ ) and $10 \%$ chopped straw (ash $2.4 \%$, CP 9.6\%).

Calves were sampled at the age of three months. Fecal samples were taken from each calf three times per day (in the morning shortly after feeding around $8.00 \mathrm{~h}$, at midday halfway between feedings around $13.00 \mathrm{~h}$ and in the evening shortly before feeding around $18.00 \mathrm{~h}$ ). All fecal samples were taken with rectal gloves directly from the rectum, and cooled to $4^{\circ} \mathrm{C}$ until processing within 24 hours. Each sample was plated nine times (technical repeats). Quantification of $C$. perfringens was performed as follows. One gram of the fecal samples was suspended in $9 \mathrm{~mL}$ of PBS (phosphate buffered saline). Ten-fold dilutions were made in sterile PBS. Subsequently, for each dilution, six droplets of $20 \mu \mathrm{L}$ were plated on Columbia agar (Oxoid, Basingstoke, UK) with 5\% defibrinated sheep blood, containing $12 \mathrm{mg}$ kanamycin sulphate and 30,000 U/1 polymyxin B sulphate. Bacteria were allowed to grow overnight at $37^{\circ} \mathrm{C}$ in an anaerobic cabinet (Ruskinn Technology, Bridgend, UK) with $84 \% \mathrm{~N}_{2}, 8 \% \mathrm{CO}_{2}$ and $8 \% \mathrm{H}_{2}$. The identification of $C$. perfringens colonies was made on the basis of a dual hemolysis zone. The number of CFU of $C$. perfringens per $\mathrm{g}$ feces ( $=$ fecal clostridial count $(\mathrm{FCC})$ ) was calculated based on the recovered colonies on the plates. To determine the effect of the diet on the FCC, a linear mixed model with repeated measurements was built with clostridial count (in CFU/g feces) as outcome variable. For each calf, three observations were added, one at each time point (morning, midday and evening). Each observation consisted of the mean of nine FCC performed on each sample. The outcome variable was tested for normal distribution. Time (morning-midday or evening) was added as a repeated measurement and a variance components covariance structure was used. Calf was added as a random effect to account for clustering of samples within a calf. Feeding regime (Group 1 or 2) was added as a fixed factor. Significance was set at $\mathrm{P}<0.05$. All analyses were performed in SAS 9.4 (SAS Institute Inc., Cary, NC), using the PROC MIXED procedure.

Mean \pm SD FCC was $505 \pm 1059 \mathrm{CFU} / \mathrm{g}$ feces and $56 \pm 119 \mathrm{CFU} / \mathrm{g}$ feces in groups 1 and 2, respectively. The effect of the test group was significant at every time point $(\mathrm{P}<0.001)$. The time effect $(8.00 \mathrm{~h}, 13.00 \mathrm{~h}$, $20.00 \mathrm{~h}$ ) was not significant (Figure 1).

The study of risk or protective factors for enterotoxemia is seriously hampered by the fact that this is a rare event disease (Lebrun et al., 2010). Unrealistically large sample sizes need to be taken into account

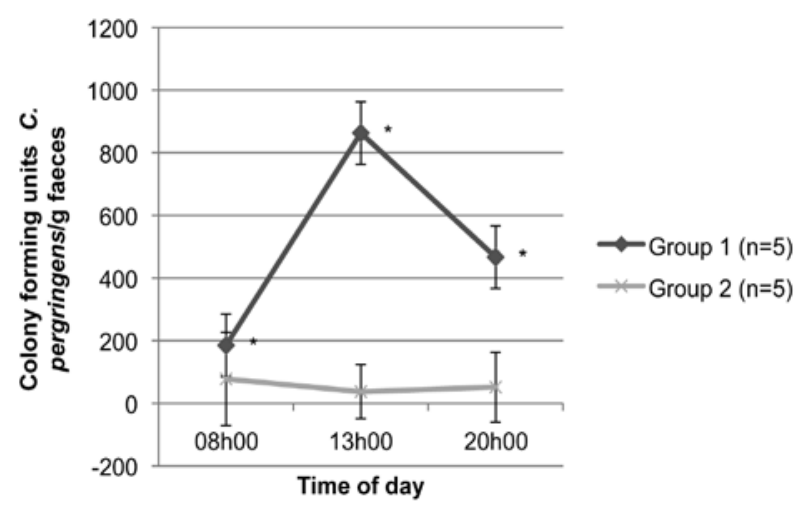

Figure 1. Evolution of the mean fecal clostridial counts (CFU/g feces) in veal calves receiving only milk replacer (group 1) or milk replacer and solid feed (group 2). Error bars represent the standard deviation; * indicates a significant difference $(P<0.001)$ between the two groups at that time. 
when looking at mortality due to enterotoxemia as the outcome variable. Therefore, alternatively, the effect of solid feed provision on fecal $C$. perfringens excretion was determined. The authors want to stipulate that the observations made in this study refer to FCC. Evidencing a direct link with enterotoxemia was not the objective. Higher FCC suggests an increased clostridial load in the intestinal microbiota, which may contribute to a higher risk of $C$. perfringens induced enterotoxemia. However, there is no known FCC threshold that would result in enterotoxemia.

The present study showed that supplying solid feed decreases fecal clostridial excretion in veal calves. The mechanism behind this effect is not completely understood. Veal calves fed exclusively milk replacer only develop a rudimental rumen (Suarez et al., 2007). In the veal calves offered solid feed, the limited amount of $300 \mathrm{~g}$ per feeding even induced relevant ruminal development and an active ruminal function (Webb et al., 2013). This might lead to an intestinal environment less favorable for Clostridia, possibly favoring bacteria with a direct $C$. perfringens growth-inhibiting effect, such as for example Bacillus subtilis (Jeong and Kim, 2014). Fiber-rich feeds indeed do increase the proportion of Bacillus spp. in the ruminal microbiota, potentially inhibiting clostridial overgrowth (Zhang et al., 2013). Moreover, veal calves fed milk replacer and solid feed have an improved ruminal digestibility (Labussiere et al., 2009), potentially leading to a decreased availability of nutrients in the lower intestine, and thus leading to a lower FCC. Although the association between FCC and enterotoxemia risk remains to be determined in calves, the provision of solid feed to veal calves might be a useful preventive tool against enterotoxemia. This opens perspectives for further dietary management of the disease. It remains to be determined whether the composition of the solid feed can be optimized in order to reduce FCC even further.

\section{ACKNOWLEDGEMENTS AND CONFLICT OF INTEREST STATEMENT}

This study was in part supported by the IWT grant LO 09 910. The authors would like to thank all contributing farmers and veal cooperatives for their kind cooperation. None of the authors has any financial or personal relationships that could inappropriately influence or bias the content of the paper.

\section{REFERENCES}

Glock R.D., Degroot B.D. (1998). Sudden death of feedlot cattle. Journal of Animal Science 76, 315-319.

Griner L.A., Brackken E.K. (1953). Clostridium perfringens (type C) in acute hemorrhagic enteritis in calves. Journal of the American Veterinary Medical Association 122, 99-102.

Jeong J.S., Kim I.H. (2014). Effect of Bacillus subtilis C-3102 spores as a probiotic feed supplement on growth performance, noxious gas emission, and intestinal microflora in broilers. Poultry Science 93(12), 3097-3103.

Labussiere E., Dubois S., Van Milgen J., Bertrand G., Noblet J. (2009). Effect of solid feed on energy and protein utilization in milk-fed veal calves. Journal of Animal Science 87(3), 1106-1119.

Lebrun M., Mainil J. G., Linden A. (2010). Cattle enterotoxaemia and Clostridium perfringens: description, diagnosis and prophylaxis. Veterinary Record 167, 13-22.

Muylaert A., Lebrun M., Duprez J. N., Labrozzo S., Theys H., Taminiau B., Mainil J. (2010). Enterotoxaemia-like syndrome and Clostridium perfringens in veal calves. Veterinary Record 167, 64-65.

Niilo L., Harris W.N., Jones G.A. (1974). Clostridium perfringens type $\mathrm{C}$ in hemorrhagic enterotoxaemia of neonatal calves in Alberta. CanadianVeterinay Journal 15, 224-226.

Pardon B., De Bleecker K., Hostens M., Callens J., Dewulf J., Deprez P. (2012). Longitudinal study on morbidity and mortality in white veal calves in Belgium. BMC Veterinary Research 8, 26.

Suárez B.J., Van Reenen C.G., Stockhofe N., Dijkstra J., Gerrits W.J. (2007). Effect of solid feed source and solid feed to concentrate ratio on animal performance and rumen development in veal calves. Journal of Dairy Science 90(5), 2390-2403.

Webb L.E., Bokkers E.A., Heutinck L.F., Engel B., Buist W.G., Rodenburg T.B., Stockhofe-Zurwieden N., Van Reenen C.G. (2013). Effects of solid feed source, amount, and particle size on behavior and gastrointestinal health of veal calves. Journal of Dairy Science 96(12), 77657776.

Zhang R., Zhu W., Zhu,W., Liu J., Mao S. (2014). Effect of dietary forage sources on rumen microbiota, rumen fermentation and biogenic amines in dairy cows. Journal of the Science of Food and Agriculture 94, 1886-1895. 